\title{
Paracrisis and Social Media: A Social Network Analysis of Hashtag \#uninstallbukalapak on Twitter
}

\author{
Acniah Damayanti ${ }^{1, a)}$ \\ ${ }^{1}$ Communication Science Department at Universitas Gadjah Mada, Yogyakarta \\ a) author correspondence: acniah.damayanti@ugm.ac.id
}

DOI: https://doi.org/10.18196/ikm.121032

Article Info

Article history:

Received 5 Dec 2019

Revised 8 Apr 2020

Accepted 5 May 2020

\section{ABSTRACT}

Social media has become a double-edged sword for crisis management. It poses both opportunities and challenges. One of the challenges is that social media themselves could risk the organization by generating crisis-threat and amplify it. This crisis-threat is termed as paracrisis, and \#uninstallbukalapak is an example of paracrisis. The Twitter public created this hashtag as a response to Achmad Zaky's, the CEO, tweet that allegedly criticized the incumbent presidential candidate. Using the exploratory Social Network Analysis method, this research investigated the formation of \#uninstallbukalapak paracrisis by identifying the most influential actors in the network discussion of \#uninstallbukalapak on Twitter and investigated what topics were in the discussion. This research found that the most influential actors in the network of \#uninstallbukalapak were @achmadzaky,@bukalapak, and @jokowi. Topics mainly discussed were mistake attribution to Achmad Zaky, the association of \#uninstallbukalapak hashtag with presidential candidate support, and also the expression of public support to Achmad Zaky and Bukalapak.

Keywords: Exploratory Social Network Analysis; Social Media; Paracrisis

\section{ABSTRAK}

Media sosial mempunyai dua sisi mata uang dalam lingkup manajemen krisis, ia menyajikan peluang sekaligus tantangan. Tantangan yang dihadirkan oleh media sosial salah satunya adalah bahwa platform itu sendiri mempunyai risiko untuk menjadi lanskap pembentukan krisis yang dapat menjadi ancaman bagi reputasi perusahaan. Risiko krisis yang berpotensi mengancam ini disebut juga sebagai paracrisis. Salah satu kasus paracrisis yang bermula dari media sosial adalah tagar \#uninstallbukalapak yang diinisiasi publik Twitter sebagai respon terhadap twit CEO Bukalapak, Achmad Zaky, yang dinilai mengandung kritik bagi kandidat presiden petahana. Menggunakan metode analisis jejaring sosial eksplanatori, penelitian ini mengurai pembentukan paracrisis \#uninstallbukalapak dengan mengidentifikasi aktor yang berpengaruh dan juga tema diskusi yang muncul di dalam jejaring media sosial Twitter. Penelitian ini menemukan bahwa aktor atau akun paling sentral dalam jejaring tagar \#uninstallbukalapak adalah@achmadzaky, @bukalapak, dan@jokowi. Adapun topik diskusi yang muncul di dalam jejaring dan mengamplifikasi \#uninstallbukalapak diantaranya adalah atribusi kesalahan kepada Achmad Zaky, asosiasi tagar terhadap dukungan kepada calon presiden, dan juga dukungan terhadap Achmad Zaky dan Bukalapak.

Kata Kunci: Analisis Jejaring Sosial Eksploratori; Media Sosial; Paracrisis 


\section{INTRODUCTION}

Advancement in technology provides an organization with a more accessible connection to its stakeholders. Recently, a stakeholder is easier to reach its organization through various platforms in internet-mediated communication. Consider social media, in that platform, a consumer of a company can transmit its complaint without mediation to the company, or even make the reservation viral. An organization cannot fully curb and anticipate the effect, the response, and reproduction of the message of audiences since the audiences can unrestrictedly send, receive, and reproduce the message to be used by other recipients (Aula, 2010). However, despite the high risk of crisis threat, social media use is inevitable. Therefore, organization visibility and willingness of the organization to open their communication channel with their stakeholder by using social media is considered urgent to be realized in this era (Merkelsen, Möllerström, \& von Platen, 2016).

On the one hand, social media is capable of increasing organization visibility and being a device in monitoring stakeholder's perception and expectation towards the company; on the other hand, it can also increase the visibility of problems faced by the organization and public scrutiny towards the organization itself (Roh, 2017). Pang, Abu Hassan, and Chong (2014) analogized social media to breeding grounds. Social media is a room that enables information to spread fast and extensive (Aula, 2010). With its network, social media can also be considered a capable echo chamber for amplifying not only information but also misinformation quickly (Fearn-Banks, 2011), and that character admittedly is risky for an organization. Risk of the crisis itself is defined as a gap between organization reputation and what genuinely happen in reality, such as changes in stakeholder expectation and incapability of internal part of the organization in responding the alteration that occurs in either the internal or external part of the organization (Eccles, Newquist, \& Schatz, 2007). Risk and crisis are not only constructed by physical or technical experience owned by individuals or groups but also shared-perception, which is formed and disseminated through media channels (Yannopoulou, Koronis, \& Elliott, 2011), including social media. The character of the echo chamber owned by social media can accelerate the dissemination of shared-perception by taking advantage of the range and influence of the public that is wider and more challenging to be predicted.

Coombs dan Holladay (2012) used a term called paracrisis to point out to risk or crisis threat that comes from social media and is observed and perceived by the public as irresponsible or unethical action from the organization. According to Coombs and Holladay, paracrisis is not a crisis per se. Rather, it is a situation that resembles a crisis, which, if it is not mitigated accurately, can escalate to be a crisis and harm the organization's reputation. Paracrisis comes before a crisis and appears in the prevention stage in crisis management scope. However, although it may threaten companies' reputation and requires an immediate response from the organization, paracrisis does not massively affect the operation of the organization as the crisis does (Kim, Zhang, \& Zhang, 2016). In this respect, Coombs and Holladay (2012) proposed three methods that can be opted by the organization in responding to paracrisis, namely refuse, refute, and reform. In refuse, the organization does not give a response to public scrutiny or issues that are circulated in public on social media and let paracrisis pass on by itself with an understanding that it may not endanger the reputation of the organization. Refuse is more defensive by objecting to the claim and negative sentiment of the public towards the organization. Reform, differently, encourage the organization to admit that the action that becomes the public concern is an improper practice and execute transformation or adjustment.

One case of paracrisis in Indonesia is the emergence of hashtag \#uninstallbukalapak on Twitter. This hashtag emerged due to a personal tweet from the CEO of Bukalapak, Achmad Zaky, in February 2019. In his tweet, Achmad Zaky associated the project Industry 4.0 with limited funding allocation for Indonesian research and development (Tirto.id, 2019, February 15a). In his tweet, Ahmad Zaky expected that the new president from the General Election 2019 was willing to raise the budget. The phrase "the new president" here was perceived by Twitter's audiences as a denotation to the other presidential candidate, outside President Joko Widodo as the incumbent. This tweet was publicly perceived as an attempt to attenuate Joko Widodo's image.

Public on Twitter who disagreed with Achmad Zaky initiated hashtag \#uninstallbukalapak. This tweet used to be the number one trending topic on Twitter, with the number of tweets amounted to 60.000 tweets (Tirto.id, 2019, Februari 15b). This event concerned Achmad Zaky, and he immediately deleted the controversial tweet after the tension escalated and met President Joko Widodo in person to apologize for that case. After the meeting, Jokowi encouraged the public to forsake the movement of \#uninstalbukalpak (Kompas.com, 2019, February 16). Although, as stated in 
previous research, the antecedent of paracrisis in an organization is typically an official message or statement from the official channel (Bogomoletc, 2019; Kim et al., 2016), and not the opinion or personal view of a member of the organization, in Achmad Zaky's case, his personal opinion bore potential damage to the brand Bukalapak's reputation. The public highlighted and maligned Achmad Zaky not as a citizen but as the CEO of Bukalapak. The hashtag \#uninstallbukalapak burst as a response affecting the brand safety of Bukalapak.

With that case in mind, the research tries to find the forming process of the paracrisis \#uninstalbukalapak by studying the circulation of information on the network and identifying actors that were impactful in creating discussion and topics that emerge on the network. The actors that were influential on the network were considered to have a major role in influencing individual behaviors on the networks adequately (Wardyaningrum, 2019: 21). This investigation towards the social network was performed based on the measurement of the relationship between actor and the centrality of the actors (Everett, Borgatti, \& Johnson, 2013; Golbeck, 2013) and community membership, or the cluster-forming of the individuals on the networks (Kennedy, Moss, Birchall, \& Moshonas, 2013). Academically, this research contributes to the study of crisis management and risk communication by using big data to analyze the forming process and risk amplification in social media networks. So far, topics regarding internet role in amplifying risk or crisis on social media have not extensively studied. One of the factors is the difficulty in collecting or extracting data from the internet (Chung, 2011). Methodologically, the novelty of this research is in the data collection method and data analysis method that was sourced from the internet.

\section{METHODS}

The research used an exploratory Social Network Analysis (SNA). Exploratory SNA is social analysis network that combines quantitative and qualitative approaches in which the numeric data of the network is transformed into a graphic visualization, followed by a narrative explanation of pattern and network structure (Teddlie \& Tashakkori as cited by Nooraie, Sale, Marin, \& Ross, 2018). Exploratory SNA enables the researchers to identify the relationship between actors (Everett et al., 2013), the roles of the actor, communication pattern, and subgroup on the network (de Jong \& Zwijze-Koning, 2009). The object of the research was any tweet that contained \#uninstalbukalapak. The data were collected from microblogging Twitter by tweet scrapping. A software R performed scrapping by targeting hashtag parameter or keywords \#uninstallbukalapak. The time limitation was not turned on in the process of scrapping. All tweets containing keywords \#uninstallbukalapak were extracted. Tweets that had been extracted were moved to a data cleaning process. The data cleaning was done manually by reading all the tweets one by one and deleting irrelevant tweets to retain the validity of the research. Tweets that had been extracted after the data cleaning process accounted for 9358, and it was from the period of August 2018 to February 2019.

To find the influential actors and relationships among actors on the network, the tweet data that were obtained from the scrapping process was visualized using Gephi software. Gephi is a software that can expose the degree of graphic representation, centrality, and community membership, or cluster-forming from individuals on the network (Kennedy et al., 2013). The node and the edge on the network can be seen by looking at the Gephi network visualization. Node and edge are two substantial elements of the network analysis. The network, therefore, is an arrangement of the nodes that are connected by edges (Golbeck, 2013) where a node represents individual or actor on the network, and an edge represents connection among nodes.

In the network analysis, the centrality of the actor that is pointed out by the size of the node is an essential component (Golbeck, 2013). The centrality showed how vital or influential an actor on the network. There are some measurements for measuring network centrality, but this research used four network centrality measurements, namely, degree centrality, betweenness, closeness, and eigenvector, to find dominant actors that were influential in the discussion \#uninstallbukalapak. Buzzword visualization and semantic network analysis were carried out to find the topic of discussion on the network. A buzzword is a term to explain a topic or event that is understood and used by society (Zhang, Tomonaga, Nakajima, Inagaki, \& Nakamoto, 2016). In the social media landscape, the buzzword is ascribed to terms on social media that is comprehended and used collectively on social media (Kilyeni, 2015). Kliyeni added that buzzword might be context-specific and created to identify a particular concept or issue that is discussed on social media. A buzzword analysis was performed by identifying high-frequency terms on the network \#uninstallbukalapak. Buzzword visualization can delineate the central tendency of the topic of discussion that often emerged on the network. 
Furthermore, a semantic network can guide to look at the topic of discussion specifically by analyzing the association among terms or phrases that appear on the network. A semantic network is a network of words or phrases that has interconnectivity and can be used to explore discussion on the network by discerning context and the structure of the semantics (Drieger, 2013). A semantic network is also called knowledge representation (Batrinca \& Treleaven, 2014), namely an attempt to analyze the relationship between a term in a document. Principally, a semantic network and content analysis apply the same canon, namely marshaling words or phrase that has the same context into one category. A semantic network would be extracted automatically on the unstructured text data by using software $\mathrm{R}$. The result of extraction $\mathrm{R}$ is showed in the form of visualization of words that allay to recognize the relations and pattern of semantic structure (Drieger, 2013). The semantic analysis in this research was performed by exploring the semantic structure, analyzing the association between words and phrases on the network, and interpreting the context of conversation and issues that appeared in the discussion \#unisntallbukalapak.

\section{RESULT AND DISCUSSION}

\section{Result}

The finding will be displayed in four sections, and it will be based on the measurement of the network that includes degree, centrality (Everett et al., 2013; Golbeck, 2013), and community membership, which can be analyzed from the cluster-forming of individuals on the network (Kennedy et al., 2013). The followings are topics discussed in the cluster. The first part is the overview of the network that will explain descriptive data of the network. The second part is the visualization of networks and the centrality aspect of the actor within the network. Furthermore, the third part is the visualization of the buzzword; it is employed to understand the terms or phrases that are often used in the discussion of network cluster \#uninstallbukalapak. Finally, the last part is the visualization of semantic network that shows the relation between terms or phrase (semantic structure) that emerge in the discussion.

\section{Overview of the network}

After extracting and cleaning the data, 9358 tweets were collected. Based on the graph of tweet frequency, which was obtained from the extraction process in Figure 1, tweets that contained hashtag \#uninstallbukalapak had emerged since 2018 before Achmad Zaky's tweet about the amount of budget for Indonesian research and development took place.

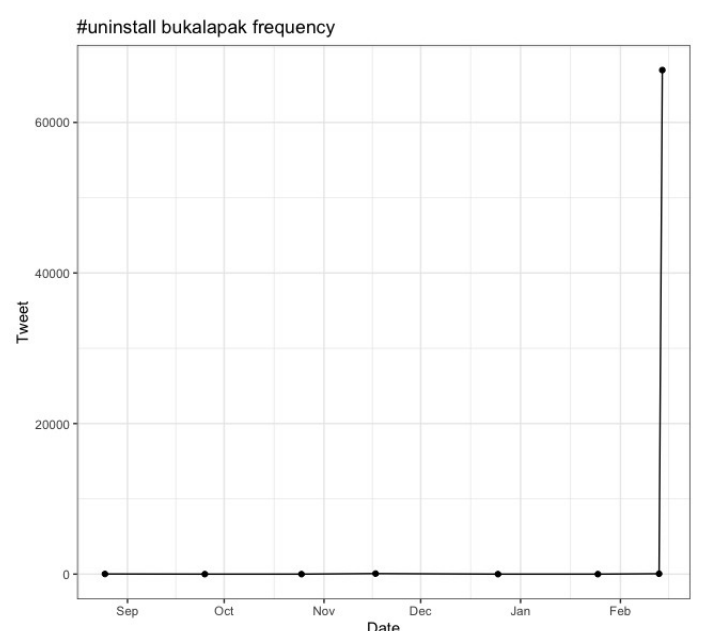

Figure 1. Timeline and tweet frequency of \#uninstallbukalapak

Tweets that emerged before the case was about customer complaints towards the service of Bukalapak and suspicion that Bukalapak would be a potential political vehicle. 
Get ready for uninstalling, going to be political vehicle@gojekindonesia@bukalapak \#uninstallgojek \#uninstallbukalapak(@bukankecebongg, August 25, 2018)

@BukaBantuan, this transaction has proceeded, and the product has been delivered. Gojek has delivered the product to the destination, while Bukalapak is still hectic with its broken system. Salute to Gojek \#uninstallbukalapak pic.twitter.com/T6nAceH6ci (@9e5592b52bd847e, November 17, 2018)

Tweet \#uninstallbukalapak that respond Achmad Zaky's tweet just appeared on February 13, 2019 and hit peak on February 14, 2019. The followings are some tweets that emerged:

$\begin{array}{lcc}\text { \#UNINSTALLBUKALAPAK } & \text { \#UNINSTALLBUKALAPAK } & \text { \#UNINSTALLBUKALAPAK } \\ \text { \#UNINSTALLBUKALAPAK } & \text { \#UNINSTALLBUKALAPAK } & \text { \#UNINSTALLBUKALAPAK } \\ \text { \#UNINSTALLBUKALAPAK } & \text { \#UNINSTALLBUKALAPAK } & \text { \#UNINSTALLBUKALAPAK } \\ \text { \#UNINSTALLBUKALAPAK } & \text { \#UNINSTALLBUKALAPAK } & \text { \#UNINSTALLBUKALAPAK } \\ \text { \#UNINSTALLBUKALAPAK Unistall@bukalapak(@latieffebrian, Februari } 13 \text { 2019) }\end{array}$

No shame. The government has assiduously buttressed the creative economy, even until established Bekraf that is directly under the President's coordination. This person started to play politics. You will meet your Waterloo \#UninstallBukaLapak (@SiRajaNabarat17, February 14, 2019)

After reaching the peak on February 14, 2019, a discussion with hashtag \#uninstallbukalapak in the next days disappeared. The reason probably is that on February 14, Achmad Zaky clarified and deleted his tweet that he posted a day before.

\section{Network Centrality}

1. Degree Centrality

In degree centrality, the more edges that are owned by a node, the more central the place of the node on the network (Golbeck, 2013). Based on the visualizations of figure 2, the nodes with the biggest size or the most central actor are@achmadzaky and@bukalapak, respectively. Other actors that are also vital in this network are marketplace accounts, such as @tokopedia, @lazadaID, and @ShopeeID, as well as @jokowi. For hashtag \#uninstallbukalapak, @achmadzaky and @bukalapak were two accounts that often get mentioned (in-degree centrality), making their edge's number high compared to other nodes on the network.

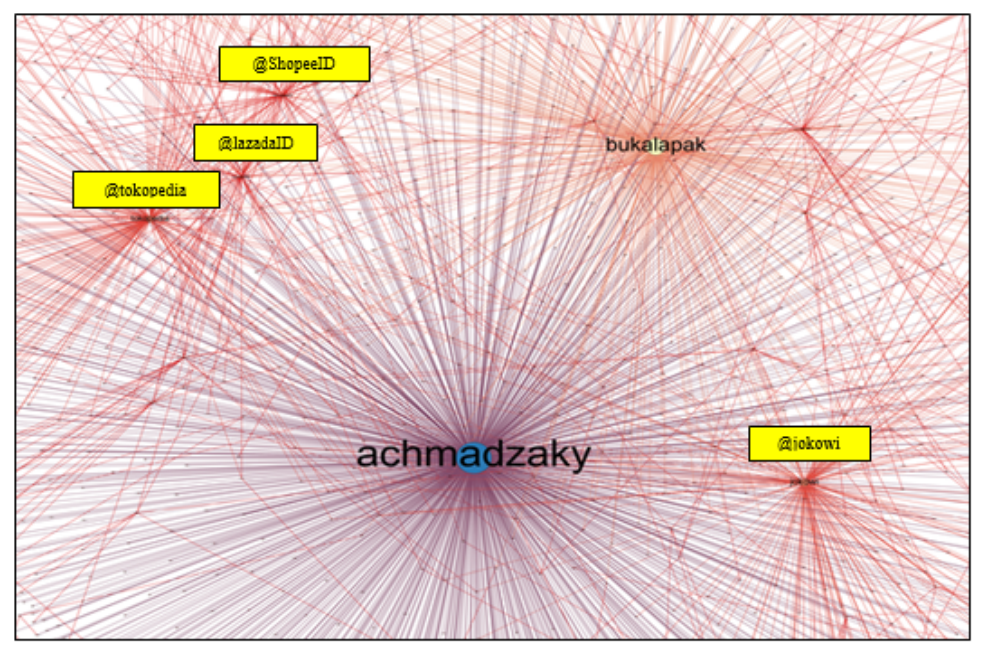

Figure 2. Visualization of degree centrality 


\section{Betweenness Centrality}

Based on the principle of betweenness centrality (Golbeck, 2013), the node that becomes an intersection of many other nodes in delivering and receiving messages is a node that is central or influential. The reason the position of the note on the network is essential is its function in arranging information circulation on the network. Tie-strength or relation power on the network is weak since the nature of the relationships among users is not close or mutual. In the context of weak tie-strength, the level of betweenness of a higher node indicates that the node has many followers, i.e., that node has many accounts or users on the network. Based on the visualization of figure 3, the most central nodes are@achmadzaky,@bukalapak,@tokopedia,@lazadaID, @ShopeeID, and@jokowi, respectively.

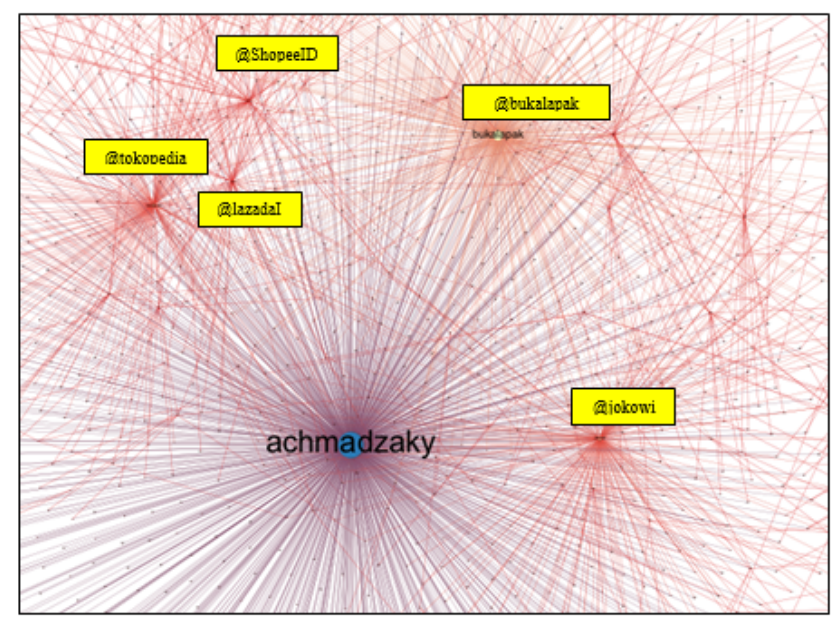

Figure 3. Visualization of betweenness centrality

\section{Closeness Centrality}

In the closeness centrality measurement, a node is deemed central if it is close to most of the nodes on the network (Golbeck, 2013). Node with a high level of closeness typically is placed in the middle of other nodes on the visualization of the network. As reflected in Figure 4, nodes that have the highest level of closeness on the network are@achmadzaky, @bukalapak, @jokowi, dan (a)tokopedia.

The character of the edge on the network is directed edge, indicating a one-way communication. The accounts that included hashtag \#uninstallbukalapak in his tweet mostly only communicated or mentioned the accounts of@achmadzaky,@bukalapak,@jokowi, and other marketplace's accounts, such as@tokopedia, without communication process, or connected to other accounts. That is,@achmadzaky,@bukalapak,@jokowi, and@tokopedia, become account that has a high level of closeness since the account is the most connected with other accounts.

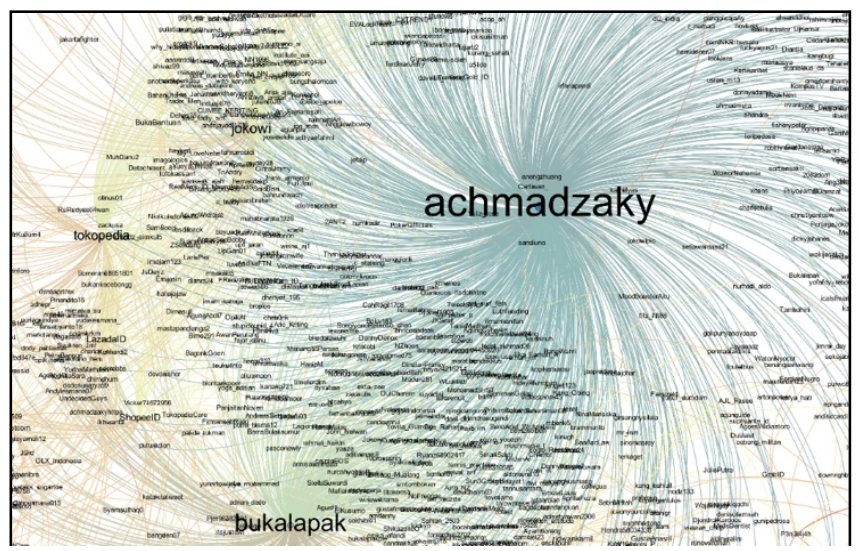

Figure 4. Visualization of closeness centrality 


\section{Eigenvector Centrality}

The centrality level of a node can be measured by looking at the influence or popularity of nodes that are close to the node (neighboring nodes) (Golbeck, 2013). Based on the measurement of eigenvector, the central actors on the network of hashtag \#uninstallbukalapak are @achmadzaky and @bukalapak, as shown in Figure 5. The neighboring nodes of the accounts of @achmadzaky and @bukalapak that were influential and often appeared on the discussion are @jokowi and other online marketplace accounts, such as @tokopedia, @lazadaID, and @.ShopeeID, in which each account also has numerous followers.

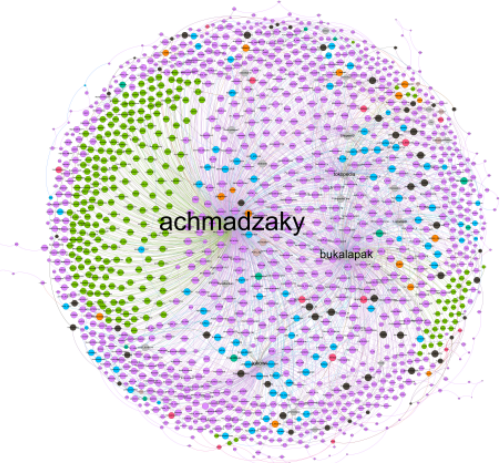

Figure 5. the visualization of eigenvector centrality

\section{a. Buzzword}

A buzzword is a term that is created and understood collectively. It is used in the specific topic of discussion on social media (Kilyeni, 2015). Figure 6 is the visualization of a buzzword of discussion of hashtag \#uninstallbukalapak on Twitter. Some buzzwords that appeared represent the perception of netizens towards Achmad Zaky, who is considered not respectful of the support that was given by the administration of President Joko Widodo to his business. Buzzword \#unisntallbukalapak then emerged as the response of netizens. In addition to \#uninstallbukalapak, the netizens also used buzzword that seems similar, namely \#lupabapak (\#forgettingfather), since the attitude of Achmad Zaky is deemed not respectful toward Joko Widodo's aid.

Data from 2013 when president @jokowi had not run the office, and when he took office, he proudly endorsed works of Indonesian citizens that enabled many of them to become big as now. But, he stabbed in the back proudly and arrogantly by saying "NEW PRESIDENT" let's see. \#UninstallBukalapak (@Pelukdulusinii, February 14, 2019)

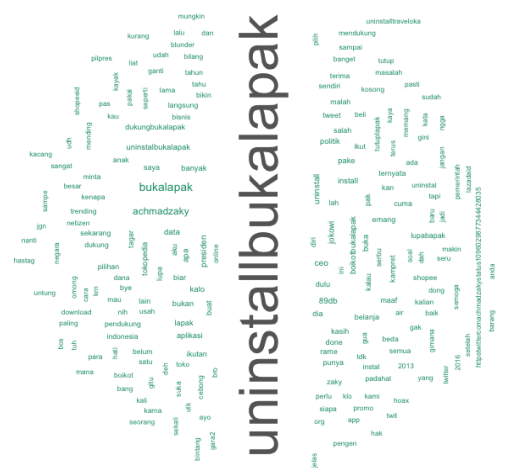

Figure 6. the Visualization of nework buzzword of hashtag \#uninstallbukalapak

The term 'support' became a buzzword with relatively negative sentiments. The term "support" that was used by Twitter's audiences represented their perception towards the political attitude of Achmad Zaky, which was suspected of tending one candidate. Even hashtag 
\#dukungbukalapak that ideally contained positive sentiment for Bukalapak was perceived as a political alignment by the netizen so as not to support Bukalapak.

Why \#dukungbukalapak if there is another candidate that can be supported? Like@tokopedia and the other, they do not conflate business with politics \#uninstallbukalapak \#dukungtokopedia \#dukungshopee (@harrizmuhamad_February 14,2019)

Buzzwords that appeared beforehand but having an association with this issue emerged in the discussion, such as 'cebong' (tadpole) and 'kampret' (bat). Cebong is the allusion for Joko Widodo's supporters, while Kampret is the inverse. Kampret is ascribed to Achmad Zaky because his criticism towards the budget of Indonesian research and development was an unsupportive gesture towards Joko Widodo. The term cebong was ascribed to the users that initiated hashtag @ uninstallbukalapak. A stereotype then was produced that netizens that initiated the uninstall Bukalapak app as Joko Widodo's supporters.

It is not a problem if Zaky supports Prabowo. The problem is now I have found out that after all this time I have shopped with Kampret \#uninstallbukalapak (@AbamBram, February 14, 2019)

It is normal that cebong initiated \#uninstallbukalapak since no payment method offer a credit \#JokowerSakitJiwa \#JkwRajaHutang \#JumatJkwNgibulDimanapic.twitter.com/HzrD4KA5xw (@Chandra_lpg,February 14, 2019)

b. Semantic Network

Figure 7 is the result of the automatic extraction of the semantic network through Software $\mathrm{R}$.

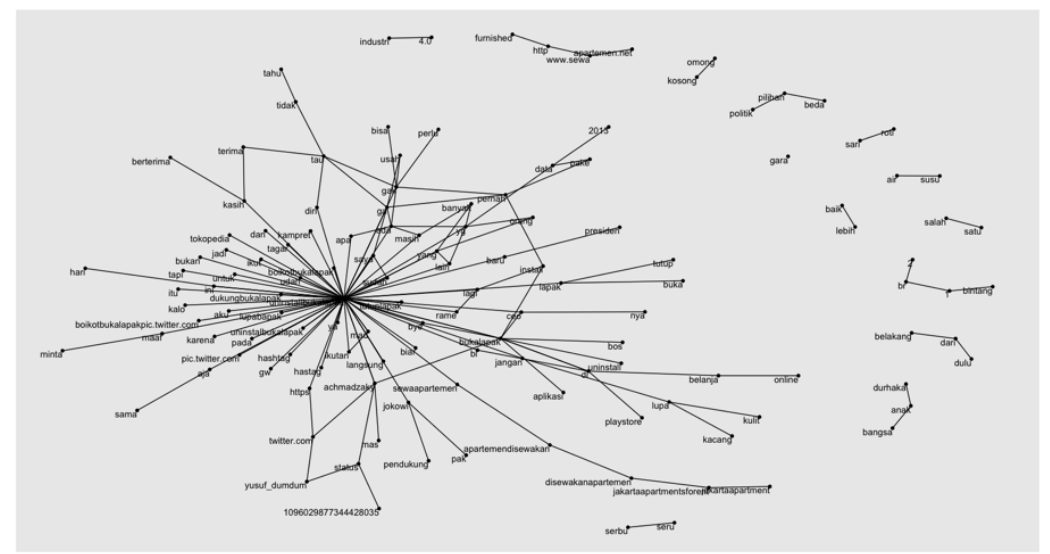

Figure 7. Visualization of semantic network

If, on the visualization of buzzwords, the words that were often used were independent, on the visualization of the semantic network, the words or phrases witness associated or hierarchal. The term 'supporter" in Figure 7 above, for example, is related to the terms 'jokowi,' 'mister,' and 'uninstallbukalapak.' Semantically, this finding can be read in the discussion of \#uninstallbukalapak. The terms supporter typically appeared together with terms or phrases that relate and create a structural meaning.

When the supporters of @jokowi created \#UNINSTALLBUKALAPAK, the kampret said that we should not get a hard feeling. You said we have to support UMKM (small and micro business), this is the reason why we have to \#dukungbukalapak. Ridiculous! do not play wisely. When Ust. @yusufmansurnew supported Jokowi, you said that Payten is forbidden (@zahiratan4, 14 February 2019) 
Another example is the term "2013" that was related to the term 'data.' The two terms that were often used concurrently refer to Tweet "Achmad Zaky" which be the source of the controversy. Achmad Zaky tweeted that his data that he used to compare the budget of Indonesian research and other countries was sourced from 2016. The netizen argued that Achmad Zaky used 2013 data, making his claim invalid. Tirto, an online media, also verified the source of the data and confirmed that Achmad Zaky's data was from 2013 (Tirto.id, 2019, February 15b).

The mistake of@achmadzaky is that he mentioned that his data of the budget of Indonesian research and development was from 2016, while that data was from 2013. Does it look political? It is ironic with his status that as high as CEO cannot be honest regarding the reliable data. It is better for you to just silence than making a quarrel... \#uninstallbukalapak (@brian_gemilang, February 14, 2019)

Based on the finding of centrality, buzzword, and semantic network, the actors that were dominant and the influence on the network, and topic of discussion that emerged on the case of paracrisis, that is faced by Bukalapak will be discussed.

\section{DISCUSSION}

According to Coombs and Holladay (2012), paracrisis is a risk of crisis that needs to manage since it may produce real exigency. The paracrisis of \#uninstallbukalapak can be categorized as a challenge (Coombs, 2014) seen from the public response. The claim of the public towards Achmad Zaky and Bukalapak was around social and political issues that were contentious and salient when Achmad Zaky posted the tweeted. The research found that hashtag or buzzwords \#uninstallbukalapak had appeared since mid-August 2018, despite not viral. That is, there had been a risk of crisis before escalated when Achmad Zaky posted his critical tweet concerning one of the policies of the incumbent candidates before the 2019 Indonesian general election. This tweet was deemed representing Achmad Zaky's political attitude as CEO Bukalapak. Visibility of Achmad Zaky as the CEO got public scrutiny to be intensive so that what was perceived by the public as wrong, not ideal, or irresponsible can immediately go viral shortly (buzzword \#uninstallbukalapak arose on February 13, 2018, being viral on February 14, 2018). This hashtag became viral because Achmad Zaky was an influencer or user that had influence, not to mention \#uninstallbukalapak contained a robust negative emotional appeal. Social media users tend to look for information and share information using buzzword \#uninstallbukalapak.

Based on the measurement of network centrality, the patterns that were relatively uniform from four different parameter measurement (degree, betweenness, closeness, dan eigenvector) was found. The most central actor in these four measurements were the accounts of@achmadzaky,@bukalapak, and@jokowi, in turn. In this vein,@achmadzaky,@bukalapak, and@jokowi were not the influencers that made the hashtag \#uninstallbukalapak viral. Instead, they were subject to scrutiny from the public that rose the hashtag. Besides these three accounts, @tokopedia, @lazadaID, and @.ShopeeID, were also mentioned by the netizen when they discuss \#unistallbukalapak. In general, this other marketplace was mentioned to be compared with Bukalapak. Also, it is for giving an alternative to moving to different applications after Bukalapak has been uninstalled.

The character of the network in the discussion of \#uninstallbukalapak was a directed network with an indication that the communication process inside it was not reciprocal. The relation among users was not mutual, and almost all messages were directed to the central actor without feedback from other central actors on the network. As a result, many nodes or actors on the networks only have edge or relation with one sum. Characteristic of this network seems to have weak tie strength among actors, implying flexibility on the information circulation on the network, enabling hashtag \#uninstallbukalapak to tend to be viral.

Based on the visualization of buzzwords and semantic network, the topic of discussion that emerged and made the issue of Achmad Zaky and Bukalapak amplified is as follows:

1. Mistake attribution to Achmad Zaky

At least three errors were attributed to Achmad Zaky regarding his statement on Twitter. Firstly, data that was showed by Achmad Zaky was invalid since part of the data was known by the public as data from 2013, while reference that was given by Achmad Zaky for the aggregate data was from 2016. The public associated this error with Achmad Zaky's capacity as CEO, which ideally, as expected by the public, should not indiscriminately use data. 
Why data from 2013 was said from 2016, please mister, do not steer people by sharing random data ... you are CEO, why did jus share data \#UninstallBukalapak@achmadzaky (@renatajohar,February 14, 2019)

Secondly, another error attribution to Achmad Zaky is that he did not appreciate Joko Widodo's administration towards the economic atmosphere that had supported Bukalapak. As seen on the semantic network, there was a network with term relations 'do not,' 'know,' and 'self,' (in English, it would be better to spell it with 'un' 'grateful'), indicating that those words were often be used concurrently. This network of the term refers to the meaning construction of Achmad Zaky's message that he is ungrateful or 'peanut that forgot its nutshell' (forgetting his root). Moreover, the buzzwords that say 'lupabapak, or forgettingfather, which is similar to Bukalapak, but reproduced by netizens to be a buzzword that means Achmad Zaky has forgotten the 'father,' which in this case Joko Widodo, by opposing the president's policy.

Unfortunately, you \#forgettingfather @achmadzaky because of your tweets disappointed netizens that supports@jokowi, which also loyal customers of @bukalapak! Consequently, many do \#UninstallBukalapak \#UninstallBukalapak \#UninstallBukalapak \#UninstallBukalapak \#UninstallBukalapak(@John_Nelwan,_February, 14 2019)

The third attribution is, by criticizing Joko Widodo, Achmad Zaky was deemed supporting the other candidate for the presidency, namely Prabowo Subianto. This attitude was considered not ethical by many netizens since Achmad Zaky should not politize his business by showing his political spectrum (although Achmad Zaky's tweet was uploaded from his account @achmadzaky, and not virtually mentioning Bukalapak. However, the public had associated the figure of Achmad Zaky with Bukalapak as a brand). Although there was no explicit statement that Achmad Zaky voted for one candidate for the presidency, the public interpreted the phrase 'new president' on Achmad Zaky's tweet as a wish that the next president was not incumbent. On February 14, 2019, Achmad Zaky clarified that the phrase 'new presidency' meant whoever that would be elected as the president in the 2019 general election, and not denoting to one candidate.

Busy clarifying, old man? Just admit it that you are 02's supporter \#uninstallbukalapak \#Lupalapak(@abdillahfaiz92,February14,2019)

2. Hashtag association with support to presidential candidate

The polarization of the mass of two presidential candidates made this problem seen as the polarization of political preference. Based on the sample of the tweets below, there was a stereotyping in each polar to the other polar. It can be seen from the tweets with buzzwords 'cebong,' 'kampret,' and 'sumbu pendek' (short-fussed). Since Achmad Zaky's statement was considered tending to Joko Widodo, hashtag \#uninstallbukalapak was associated with Joko Widodo's supporter. Buzzword 'cebong' and 'shortfused' then appeared on the tweets that showed disagreement with hashtag \#uninstallbukalapak. Buzzword 'kampret' emerged on the tweets that supported Bukalapak to be uninstalled. Some netizens of the opposite side did not make the problem of Achmad Zaky and Bukalapak as the main discussion instead of making it a mean to attack each other preferences.

We are obliged to sink, to be a supporter of Kampret party \#uninstallbukalapak (@TofikHi82001232,February 14,2019)

Look, short-fused people that are talkative; try to make your militant movement of \#UNINSTALLBUKALAPAK works also to cases that need support, such as towards teachers victims of assault, victims of rape, and so forth. You support 01 but cannot be stable as the presidential and vice-presidential candidates (@rzkyrd, February 14, 2019)

3. Support toward Achmad Zaky and Bukalapak

The buzzword \#unistallbukalapak did not always have a negative tone. Some tweets contained hashtag \#uninstallbukalapak but supporting the clarification tweets of Achmad Zaky or Bukalapak, apart from the political choice of the CEO. 
@achmadzaky has clarified. He said that it was a misperception. Admittedly, the phrase new president seems a bit insinuating, but if you \#uninstallbukalapak just because the person behind that supported one of the candidates, it was somewhat silly. Moreover, why did you so sensitive to people that are different (@Febriansubagja_February 14, 2019)

A variety of topics of discussion that emerged shows that the abundance of information and the plethora of the actors within the ecosystem of social media makes the process of communication inside it complex (Wendling et al., 2013). It implies to crisis management that should be concerned about the nature of the digital environment itself. Social media use by the organization itself was a factor of risks that can be included in the roadmap of organizational crisis management, whether for pre-, during, or post-crisis. This reason is mostly its character that can engender a crisis, but as well utilized as a tool to mitigate and handle a crisis concurrently.

Fast, accurate, and strategic response toward paracrisis that develop on social media became urgency in the scope of crisis management. Although it does not immediately annihilate the crisis, an accurate response can diminish the escalation of the crisis and reputational damage that may be produced by an exigency. Take Bukalapak's case; hashtag \#uninstallbukalapak responded to the statement of Achmad Zaky that took place on February 13, 2019, and directly escalated on February 14, 2019, with the number amounted to 60.000 tweets. On February 14, Achmad Zaky responded by delivering a clarification tweet and meeting President Joko Widodo to clarify that problem. Viewing from the typology of paracrisis from Coombs (2014), Achmad Zaky used the reform technique, namely admitting that there was incompatibility and thus conducting reparative action. Although Achmad Zaky's clarification tweet still got many negative responses from netizens, the hype of \#uninstallbukalapak diluted fast. It does not mean that buzzword \#uninstallbukalapak may not appear again in the future when the organization faces a problematic situation that can threaten his reputation. The social memory of the audiences regarding crisis or paracrisis can be a risk factor for the organization, especially if the crisis has taken place before. It could exacerbate the impact or damage if the same risk recurs. Strategic crisis management thus becomes the key to mitigate risk factors of paracrisis so that it will not escalate to be a crisis.

\section{CONCLUSION}

In the model of Coombs' paracrisis (2014), paracrisis is a risk of crisis that was sourced from organizational misuse or improper use of social media channels. The research has found that paracrisis can be caused by not only organization misuse but also individual in the organization that was perceived as misuse by the public. As the CEO of Bukalapak, Achmad Zaky had high visibility and association that was close to the organization. Therefore, his individual action tended to be monitored by the public and perceived as the representation of the brand's action. Perception of this individual misuse, which can affect organization brand safety, needs to be analyzed in the roadmap of organizational crisis management so that this organization is capable of preparing preventive step and design response, which is accurate when paracrisis with the same symptom occurs.

\section{Limitation and Recommendation}

The research only used \#uninstallbukalap as the parameter in the data scrapping. Consequently, contextual tweets on Twitter that were not included in the searching parameter cannot be found. The use of some keywords or relevant searching parameters can extend the scope of the searching and enable more numerous data and more extensive insight. This research cannot analyze the perceived reputation or audience perception towards Bukalapak after Achmad Zaky's tweet. Apart from mapping the forming of paracrisis on social media, data triangulation by conducting surveys or interviews towards netizens will help to comprehend the audience's perception in pre and post the occurrence of paracrisis. 


\section{Acknowledgement}

This research is funded by research grant provided by the Department of Communication Science, Faculty of Social and Political Sciences, Universitas Gadjah Mada

\section{REFERENCE}

Aula, P. (2010). Social media, reputation risk and ambient publicity management. Strategy \& Leadership, 38(6), 43-49. https://doi.org/10.1108/10878571011088069

Batrinca, B., \& Treleaven, P. C. (2014). Social media analytics: a survey of techniques, tools and platforms. AI and Society, 30(1), 89-116. https://doi.org/10.1007/s00146-014-0549-4

Bogomoletc, E. (2019). Dialogic communication in faux pas paracrises. What do users want to discuss on brands' official Facebook pages? Journal of Promotional Communications, 7(1), $3-19$.

Chung, I. J. (2011). Social amplification of risk in the internet environment. Risk Analysis, 31(12), 1883-1896. https://doi.org/10.1111/j.1539-6924.2011.01623.x

Coombs, W. T. (2014). State of crisis communication: Evidence and the bleeding edge. Research Journal of the Institute for Public Relations, 1(1), 1-12.

Coombs, W. T., \& Holladay, S. J. (2012). The paracrisis: The challenges created by publicly managing crisis prevention. Public Relations Review, 38, 408-415. https://doi.org/10.1108/13632540710843913

de Jong, M. D., \& Zwijze-Koning, K. H. (2009). Communication network analysis. In O. Hargie \& D. Tourish (Ed.), Auditing organizational communication (hal. 149-166). New York: Routledge.

Drieger, P. (2013). Semantic Network Analysis as a method for visual text analytics. Procedia Social and Behavioral Sciences, 79, 4-17. https://doi.org/10.1016/j.sbspro.2013.05.053

Eccles, R. G., Newquist, S. C., \& Schatz, R. (2007). Reputation and its risks. Harvard Business Review, 85(2), 104.

Everett, M. G., Borgatti, S. P., \& Johnson, J. C. (2013). Analyzing social networks. London: Sage.

Fearn-Banks, K. (2011). Crisis communications: A casebook approach (4th ed.). London: Routledge.

Golbeck, J. (2013). Analyzing the social web. Waltham: Morgan Kaufmann.

Kennedy, H., Moss, G., Birchall, C., \& Moshonas, S. (2013). Digital data analysis: Guide to tools for social media \& web analytics and insights. Leeds. Retrieved from http://eprints.whiterose.ac.uk/114759

Kilyeni, A. (2015). Likes, tweets and other "friends": Social media buzzwords from a terminology perspective. Procedia - Social and Behavioral Sciences, 192, 430-437. https://doi.org/10.1016/j.sbspro.2015.06.059

Kim, S., Zhang, X. A., \& Zhang, B. W. (2016). Self-mocking crisis strategy on social media: Focusing on Alibaba chairman Jack Ma in China. Public Relations Review, 42(5), 903-912. https://doi.org/10.1016/j.pubrev.2016.10.004

Lim, J. S. (2017). How a paracrisis situation is instigated by an online firestorm and visual mockery: Testing a paracrisis development model. Computers in Human Behavior, 67, 252-263. https://doi.org/10.1016/j.chb.2016.10.032

Merkelsen, H., Möllerström, V., \& von Platen, S. (2016). The role of communication professionals in the digital aga-old paradoxes, new distinctions? In W. T. Coombs, J. Falkheimer, M. Heide, \& P. Young (Ed.), Strategic communication, social media and democracy: The challenge of the digital naturals (hal. 13-24). Oxon: Routledge.

Nooraie, R. Y., Sale, J. E. M., Marin, A., \& Ross, L. E. (2018). Social network analysis: An example of fusion between quantitative and qualitative methods. Journal of Mixed Methods Research, 1-15. https://doi.org/10.1177/1558689818804060

Pang, A., Abul Hassan, N. B. B., \& Chong, A. C. Y. (2014). Negotiating crisis in the Social Media environment: Evolution of crises online, gaining credibility offline. Corporate Communications: An International Journal, 19(1), 96-118. https://doi.org/10.1108/CCIJ-092012-0064

Roh, S. (2017). Examining the paracrisis online: The Effects of message sources, response strategies and social vigilantism on public responses. Public Relations Review, 43, 587-596. 
Wardyaningrum, D. (2019). Relations in the communication networks centrality for disaster risk reduction. Jurnal Komunikator, $\quad 11(1), \quad 18-27$. https://doi.org/https://doi.org/10.18196/jkm.111016

Yannopoulou, N., Koronis, E., \& Elliott, R. (2011). Media amplification of a brand crisis and its affect on brand trust. Journal of Marketing Management, 27(5), 530-546. https://doi.org/10.1080/0267257X.2010.498141

Zhang, J., Tomonaga, S., Nakajima, S., Inagaki, Y., \& Nakamoto, R. (2016). Prophetic blogger identification based on buzzword prediction ability. International Journal of Web Information System, 12(3), 267-291. https://doi.org/10.1108/IJWIS-03-2016-0013

Kompas.com. (2019, February 16). Jokowi: Stop "Uninstall" Bukalapak!. Retrieved from https://nasional.kompas.com/read/2019/02/16/13202301/jokowi-stop-uninstall-bukalapak

Tirto.id. (2019, February 15a). Uninstall Bukalapak: Wajah Brutal Masyarakat dan Politikus. Retrieved from https://tirto.id/uninstall-bukalapak-wajah-brutal-masyarakat-dan-politikus$\operatorname{dg} 7 \mathrm{D}$

Tirto.id. (2019, February 15b). Kontroversi Twit Bos Bukalapak Soal Dana Riset, Bagaimana Faktanya? Retrieved from https:/tirto.id/kontroversi-twit-bos-bukalapak-soal-dana-risetbagaimana-faktanya-dg78 